\title{
Risk factors and anti-Toxoplasma gondii and Neospora caninum antibody occurrence in dogs in João Pessoa, Paraíba state, Northeastern Brazil
}

Fatores de risco e ocorrência de anticorpos anti-Toxoplasma gondii e Neospora caninum em cães de Joáo Pessoa, Estado da Paraíba, Nordeste do Brasil

Arthur Willian de Lima Brasil ${ }^{1}$; Roberta Nunes Parentoni ${ }^{1}$; José Givanildo da Silva ${ }^{2}$;

Carolina de Sousa Américo Batista Santos'; Rinaldo Aparecido Mota²; Sérgio Santos de Azevedo ${ }^{1 *}$

\begin{abstract}
${ }^{1}$ Laboratório de Doenças Transmissíveis, Programa de Pós-graduação em Medicina Veterinária, Universidade Federal de Campina Grande - UFCG, Patos, PB, Brasil

${ }^{2}$ Departamento de Medicina Veterinária, Universidade Federal Rural de Pernambuco - UFRPE, Recife, PE, Brasil
\end{abstract}

Received November 6, 2017

Accepted January 17, 2018

\begin{abstract}
The aim of this study was to determine the occurrence of infections due to Toxoplasma gondii and Neospora caninum and corresponding risk factors among dogs attended at veterinary clinics in the city of João Pessoa, Paraíba, northeastern Brazil. Blood samples were collected from 384 dogs that were attended at 34 veterinary clinics between April 2015 and May 2016. These two agents were diagnosed through the indirect immunofluorescence reaction (IFAT). Among the 384 animals evaluated, $37(9.6 \%)$ were positive for T. gondii, with titers ranging from 16 to 512. Six dogs (1.6\%) were positive for $N$. caninum, with titers of 50 to 200 . Access to the streets ( $\mathrm{OR}=4.60 ; 95 \% \mathrm{CI}=1.74-12.20)$ and environments close to forested areas $(\mathrm{OR}=2.79 ; 95 \% \mathrm{CI}=1.32-5.93)$ were found to be risk factors for $T$. gondii infection. The dogs attended at veterinary clinics in João Pessoa are exposed to infections caused by T. gondii and N. caninum. Dog owners should avoid having access to the street or contact with forest environments.
\end{abstract}

Keywords: Toxoplasmosis, neosporosis, domiciled dogs, Northeastern Brazil.

\section{Resumo}

O objetivo deste trabalho foi determinar a ocorrência e os fatores de risco das infecçóes por Toxoplasma gondii e Neospora caninum em cáes atendidos em clínicas veterinárias da cidade de Joáo Pessoa, Paraíba, Nordeste do Brasil. Foram colhidas 384 amostras de sangue cães procedentes de atendimento de 34 clínicas veterinárias, no período de abril de 2015 a maio de 2016. O diagnóstico para os dois agentes foi realizado pela reação de imunofluorescência indireta (RIFI). Dos 384 animais avaliados 37 (9,6\%) foram positivos para T. gondii com títulos variando de 16 a 512 . Para $N$. caninum seis $(1,6 \%)$ cães foram positivos com títulos de 50 a 200. Foram constatados como fatores de risco para T. gondii as variáveis acesso à rua $(\mathrm{OR}=4,60$; IC 95\% = 1,74-12,20) e ambiente próximo a matas $(\mathrm{OR}=2,79$; IC $95 \%=1,32-5,93)$. Os cães atendidos em clínicas veterinárias em João Pessoa estão expostos às infecçóes por T. gondii e $N$. caninum. Os proprietários devem evitar o acesso dos animais à rua ou o contato com ambientes florestais.

Palavras-chave: Toxoplasmose, neosporose, cães domiciliados, Nordeste do Brasil.

\section{Introduction}

The interrelations among animals, humans and the environment have intensified over recent decades, which has been causing a variety of ecological imbalances. From a public health point of view, these changes have taken on great

${ }^{*}$ Corresponding author: Sérgio Santos de Azevedo. Unidade Acadêmica de Medicina Veterinária, Laboratório de Doenças Transmissíveis, Universidade Federal de Campina Grande - UFCG, Av. Universitária, s/n, Santa Cecília, CEP 58700-970, Patos, PB, Brasil. e-mail: sergio@vps.fmvz.usp.br importance, given that there is a real possibility of increased transmission of zoonoses (ZINSSTAG et al., 2011). Thus, pets such as dogs, which are increasingly incorporated into family groups as members of the family, may play a major role in maintaining and transmitting infectious agents. They may also act as sentinels for their respective diseases (ULLMANN et al., 2008). For this reason, monitoring of diseases like toxoplasmosis and neosporosis is needed and their risks towards the ecosystem need to be assessed. 
Toxoplasmosis and neosporosis are caused by Toxoplasma gondii and Neospora caninum, respectively, which are obligate intracellular coccidian protozoa belonging to the phylum Apicomplexa. Cats and dogs are the definitive hosts of T. gondii and N. caninum, respectively. Transmission of these parasites takes place through ingestion of oocysts that are eliminated from the feces of the definitive hosts; through ingestion of tissue cysts that are present in the musculature of infected animals; and through the transplacental route (DUBEY, 2003, 2010). T. gondii is considered to be a zoonotic agent (DUBEY, 2010). On the other hand, there is no evidence of zoonotic characteristics regarding $N$. caninum, although some studies have demonstrated that humans can present antibodies against this protozoon (OSHIRO et al., 2015). Even though dogs are not definitive hosts for $T$. gondii, they have an important role in mechanical dissemination of the agent (LINDSAY et al., 1997).

In Brazil, recent studies on the seroprevalence of T. gondii in dogs demonstrated variation from $11.5 \%$ to $70.8 \%$ (DANTAS et al., 2013; LANGONI et al., 2014), while for $N$. caninum this variation was from $4.2 \%$ to $43.1 \%$ (SOUSA et al., 2012; RAIMUNDO et al., 2015). The main risk factors reported in relation to $T$. gondii were the following: contact with cats (RODRIGUES et al., 2016); male sex (LANGONI et al., 2014; RODRIGUES et al., 2016); and greater age and access to the streets (AZEVEDO et al., 2005; DANTAS et al., 2013; RAIMUNDO et al., 2015). In relation to $N$. caninum, the risk factors were homemade diets, rural environment, greater age, cleansing of the environment only done weekly and presence of rats (BRESCIANI et al., 2008, PARADIES et. al., 2007, DANTAS et al., 2013).

Epidemiological surveys on toxoplasmosis and neosporosis among dogs are of strategic public health importance, because they provide an overview of the dynamics of these diseases in a given region. Such knowledge is of major importance in places like the city of João Pessoa, Paraíba, northeastern Brazil, which has a climate and environment that are favorable for parasite development, as well as there is a lack of epidemiological data on these infections in this region. In this light, the aim of this study was to determine the anti- $T$. gondii and $N$. caninum antibody occurrence and the risk factors associated with infections in dogs attended at veterinary clinics in João Pessoa.

\section{Materials and Methods}

\section{Ethics}

All the experimental procedures were approved by the Committee of Ethics and Animal Experimentation of Federal University of Campina Grande (Protocol CEP no 010-2016).

\section{Study area}

The survey was conducted in the municipality of João Pessoa, capital city of the state of Paraíba, which has about 811 thousand inhabitants (IBGE, 2017), distributed in 59 boroughs, and with an area of preserved Atlantic Forest in the center of the urban spot and bordered by mangroves (PARAÍBA, 2014). Its climate is humid tropical, with annual average temperatures of $23^{\circ} \mathrm{C}$ and annual rainfall rate above 1,906 $\mathrm{mm}$ (PEREIRA, 2014).

\section{Sampling}

The selection of the veterinary clinics was based on data from the Regional Council of Veterinary Medicine (CRMV-PB), which has informed the existence of 40 registered clinics, however, in the on-the-spot verification four establishments had closed and in two others the owners preferred not to participate. Then, 34 veterinary clinics in the municipality of João Pessoa distributed in the four zones of the city (north, south, east and west) were used.

The minimum number of animals was determined by the formula for simple random sampling (THRUSFIELD, 2004):

$$
\mathrm{n}=\frac{\mathrm{Z}^{2} \times \mathrm{P}(1-\mathrm{P})}{\mathrm{d}^{2}}
$$

Where:

$n=$ number of sampled animals

$Z=$ value of the normal distribution for the confidence level of $95 \%$ $P=$ expected prevalence of $50 \%$ (sampling maximization)

$d=$ error of $5 \%$

In total, 384 apparently healthy dogs, unvaccinated or vaccinated over six months against leptospirosis were selected. Females in the periparturient and lactation periods were excluded from the study. The collections were carried out in the period from April 2015 to May 2016. Samples were collected by venipuncture of the cephalic or jugular vein, using vacuum tubes of $5 \mathrm{~mL}$, and sera were placed into microtubes and frozen until the serologic tests were performed.

\section{Serological diagnosis of infections due to T. gondii and N. caninum}

To detect anti-T. gondii and anti-N. caninum antibodies, the indirect immunofluorescence reaction (IFAT) was used. For $T$. gondii, the dilution of 1:16 was taken to be the cutoff point (LANGONI et al., 2014) and the technique was performed in accordance with the methodology described by Camargo (1964), using RH-strain tachyzoites recovered from mice. For $N$. caninum, the cutoff point was the dilution of 1:50 (ACOSTA et al., 2016) and the technique was performed in accordance with Paré et al. (1995), using the NC-1 strain from $N$. caninum cultured in bovine monocytes as the antigen. The slides for both tests were produced in the Laboratory of Bacterioses of Domestic Animals of the Federal Rural University of Pernambuco. In both tests, both positive and negative serum samples were used as controls. Samples with tachyzoites that demonstrated complete peripheral fluorescence were considered positive and subjected to serial dilutions, with the endpoint titer defined as the reciprocal of the last dilution showing a positive result.

\section{Risk factor analysis}

Epidemiological questionnaires were applied to dog owners in order to obtain data to be used in the risk factor analysis. The analyzed variables and their respective categories were: educational level of the owner (illiterate, incomplete primary school, complete primary school, incomplete high school, complete high school, incomplete university degree, university degree), gender (female, male), breed 
(pure-bred, crossbred), age (up to 48 months, 49 to 72 months, above 72 months), access to street (no, yes), feed (commercial food, homemade food, food scraps, raw meat), access to treated water (no, yes), reason for keeping the dog (company, guard, other), contact with dogs (no, yes), contact with bovine (no, yes), contact with equine (no, yes), contact with wild animals (no, yes), contact with cats (no, yes), contact with goats (no, yes), contact with sheep (no, yes), contact with swine (no, yes), type of housing (masonry, shacks, stilts, mud huts), where the animal is kept (soil, cement, soil/cement), environment where the animal lives (rural or urban), environment near woodlands area (no, yes), regular garbage collection (no, yes), cleaning and disinfection of the environment (daily, weekly/fortnightly, monthly), contact with flooded areas (no, yes), presence of rodents (no, yes), occurrence of abortions (no, yes), occurrence of stillbirths (no, yes), presence of ticks (no, yes).

An univariable exploratory analysis of the data was carried out for the selection of variables with $P \leq 0.2$ using the chi-square or Fischer exact tests. Subsequently the significant variables passed to a multivariable analysis using the multiple logistic regression with significant level of 5\% (HOSMER \& LEMESHOW, 2000). The adjustment of the final model was verified with the Hosmer and Lemeshow test, by which a value of $P \geq 0.05$ indicates a good fit. The collinearity between independent variables was verified by correlation analysis; for the variables with strong collinearity (correlation coefficient $>0.9$ ), one of the two variables was excluded from the multiple analysis according to the biological plausibility (DOHOO et al., 1997). Confounding was evaluated by the monitoring the alterations in the model's parameters (>20\%) when adding new variables. Data analyses were carried out using the SPSS 23.0 for Windows software.

\section{Results}

Among the 384 animals analyzed, 37 (9.6\%) were seropositive for $T$. gondii, with the following respective antibody titers and frequencies: 16 (35.1\%), 32 (18.9\%), 64 (8.1\%), $128(13.5 \%)$, $256(16.3 \%)$ and $512(8.1 \%)$. For $N$. caninum, six dogs (1.6\%) were seropositive, with titers and frequencies of $50(66.8 \%)$, $100(16.6 \%)$ and $200(16.6 \%)$, respectively. One animal was positive for both parasites. Figure 1 presents the geographical locations of the homes of the dogs that were positive and negative for $T$. gondii (Figure 1A) and $N$. caninum (Figure 1B) in João Pessoa.

In univariable analysis on the risk factors associated with $T$. gondii (Table 1), the following variables were selected: type of rearing, access to treated water, aim of rearing, contact with dogs, contact with wild animals, environment in which the animal lived, locality, frequency of cleansing of the environment and contact with rats. Through multivariable analysis (Table 2 ), the variables of access to the streets $(\mathrm{OR}=4,60 ; 95 \% \mathrm{CI}=1.74-12.20)$ and environment close to forested areas $(\mathrm{OR}=2.79 ; 95 \% \mathrm{CI}=1.32-5.93)$ were identified as risk factors for $T$. gondii. Final model presented good fit (Hosmer and Lemeshow test: chi-square $=0,102$; degrees of freedom $=1 ; P=0,749)$. There were no risk factors for $N$. caninum.

\section{Discussion}

The results found in the present study regarding the occurrence of $T$. gondii are close to those found by Dantas et al. (2013) in Natal, Rio Grande do Norte, who observed that $11.5 \%$ of the dogs were seropositive; and by Dantas et al. (2014) in Patos, Paraíba, who observed that $15.6 \%$ were seropositive. Both of those

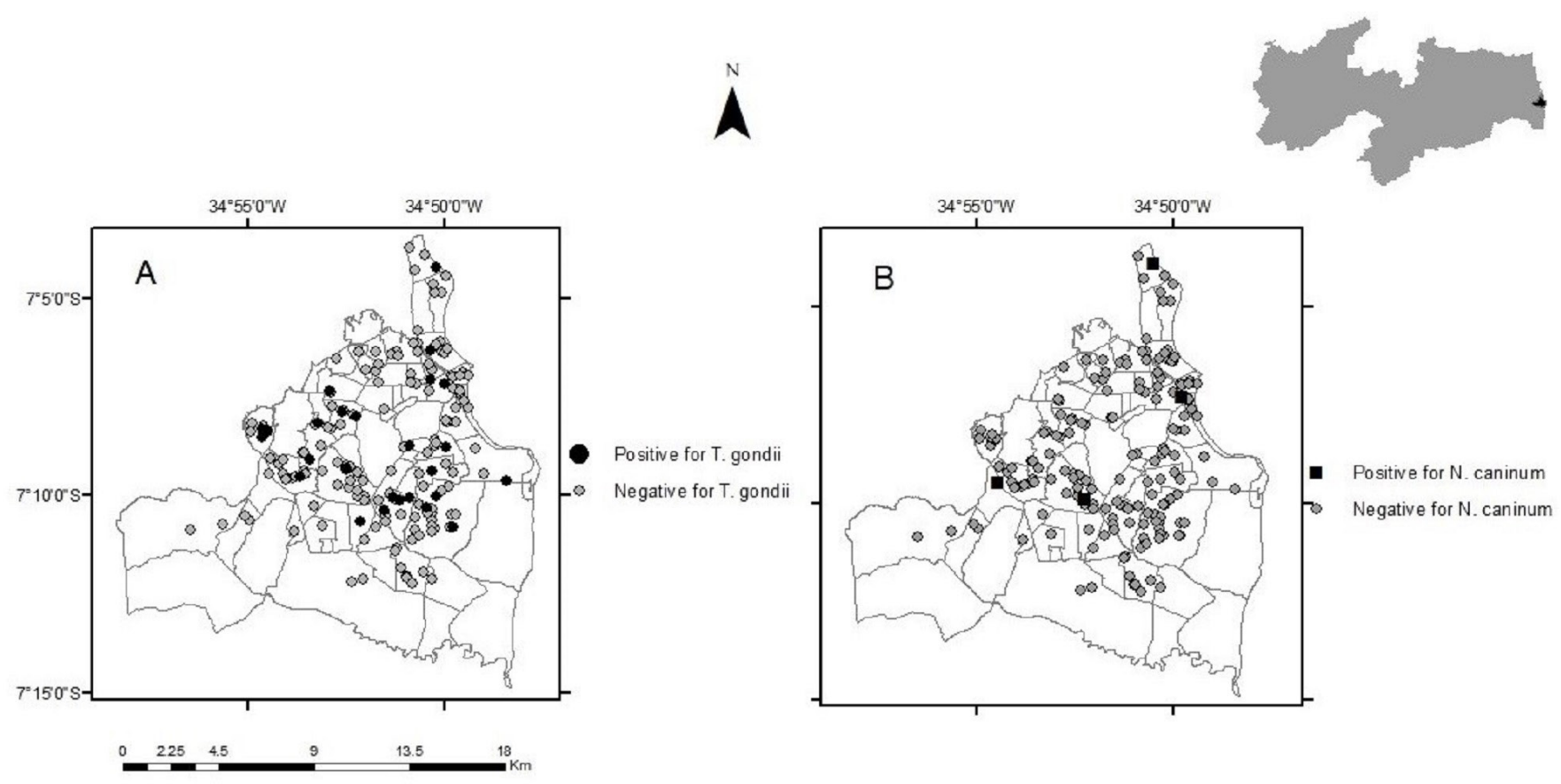

Figure 1. Geographic location of dogs attended at veterinary clinics in the city of Joao Pessoa, Paraíba, Northeastern Brazil, from April 2015 to May 2016, according to the serological condition for T. gondii (A) and N. caninum (B). The detail shows the city of João Pessoa in the state of Paraíba. 
Table 1. Univariable analysis $(P \leq 0.20)$ of the risk factors associated with seropositivity for $T$. gondii in dogs attended at veterinary clinics in João Pessoa, Paraíba, Northeastern Brazil, from April 2015 to May 2016.

\begin{tabular}{|c|c|c|c|c|}
\hline Variables & Categories & Total $n^{\circ}$ of animals & No seropositives animals (\%) & $P^{*}$ \\
\hline \multirow[t]{2}{*}{ Access to street } & No & 358 & $30(8.4)$ & 0.002 \\
\hline & Yes & 26 & $7(26.9)$ & \\
\hline \multirow[t]{2}{*}{ Access to treated water } & Não & 7 & $2(28.6)$ & 0.139 \\
\hline & Sim & 377 & $5(9.3)$ & \\
\hline \multirow[t]{3}{*}{ Reason for keeping the dog } & Company & 269 & $21(7.8)$ & 0.115 \\
\hline & Guard & 68 & $8(11.8)$ & \\
\hline & Other & 47 & $8(17.0)$ & \\
\hline \multirow[t]{2}{*}{ Contact with dogs } & No & 68 & $10(14.7)$ & 0.171 \\
\hline & Yes & 316 & $27(8.5)$ & \\
\hline \multirow[t]{2}{*}{ Contact with wild animals } & No & 368 & $33(9.0)$ & 0.057 \\
\hline & Yes & 16 & $4(25.0)$ & \\
\hline \multirow[t]{3}{*}{ Where the animal is kept } & Cement & 243 & $19(7.8)$ & 0.032 \\
\hline & Soil/Cement & 116 & $12(10.3)$ & \\
\hline & Soil & 25 & $6(24.0)$ & \\
\hline \multirow[t]{2}{*}{ Environment where the animal lives } & Rural & 30 & $5(16.7)$ & 0.191 \\
\hline & Urban & 354 & $32(9.0)$ & \\
\hline \multirow{2}{*}{ Environment near woodlands areas } & No & 192 & $11(5.7)$ & 0.009 \\
\hline & Yes & 192 & $26(13.5)$ & \\
\hline \multirow{3}{*}{$\begin{array}{l}\text { Cleaning and disinfection of the } \\
\text { environment }\end{array}$} & Daily & 287 & $23(8.0)$ & 0.138 \\
\hline & Weekly/ fortnightly & 93 & $13(14.0)$ & \\
\hline & Monthly & 4 & $1(25.0)$ & \\
\hline \multirow[t]{2}{*}{ Presence of rodents } & No & 206 & $15(7.3)$ & 0.093 \\
\hline & Yes & 178 & $22(12.4)$ & \\
\hline
\end{tabular}

${ }^{*} P$-value.

Table 2. Risk factors associated with seropositivity for T. gondii in dogs attended at veterinary clinics in João Pessoa, Paraíba, Northeastern Brazil, from April 2015 to May 2016.

\begin{tabular}{cccccccc}
\hline Varible & $\begin{array}{c}\text { Logistic regression } \\
\text { coefficient }\end{array}$ & $\begin{array}{c}\text { Standard } \\
\text { error }\end{array}$ & Wald & $\begin{array}{c}\text { Degrees of } \\
\text { freedom }\end{array}$ & Odds Ratio & CI 95\% & $\boldsymbol{P}^{*}$ \\
\hline Access to street & 1.527 & 0.497 & 9.421 & 1 & 4.60 & {$[1.74-12.20]$} & 0.002 \\
Environment near woodlands areas & 1.028 & 0.384 & 7.166 & 1 & 2.79 & {$[1.32-5.93]$} & 0.007 \\
\hline
\end{tabular}

Hosmer and Lemeshow test: chi-square $=0.102$; degrees of freedom $=1 ; P=0.749 ;{ }^{*} P$-value.

populations consisted of dogs attended at veterinary clinics, as well as the IFAT was used as diagnostic test, with titers ranging from 64 to 1,024 .

However, in an evaluation on dogs during a vaccination campaign in Campina Grande, Paraíba, Azevedo et al. (2005) found a prevalence of $45.1 \%$ using the IFAT. In this context, since the serological diagnostic method used was the same in these studies, it is believed that the characteristics of the canine population may have influenced the seroprevalence of toxoplasmosis. The dogs of the present study were attended at veterinary clinics, which leads us to believe that they were receiving better care from their owners regarding hygiene and health than were dogs that were vaccinated through public campaigns.

Although dogs that are regularly attended at veterinary clinics have received better care regarding hygiene and health (DANTAS et al., 2013), these animals may nonetheless acquire oocysts of $T$. gondii from the environment or through contact with the feces of infected cats. These oocysts may adhere to the animals' fur, which gives rise to the possibility that humans might become infected through contact with these animals. One important point is that dogs may act as sentinels for toxoplasmosis. Thus, epidemiological monitoring of the behavior of this zoonosis in these animals is immensely important (NAVA, 2008).

Dogs play a fundamental role in transmission of neosporosis to other animals, especially to cattle; however, the presence of seropositive dogs does not indicate oocyst elimination in feces (BANDINI et al. 2011). Neosporosis in cattle causes economic losses relating to abortions of the order of US $\$ 1.2$ billion worldwide (REICHEL et al., 2013). High prevalences of anti-N. caninum antibodies in dogs are generally correlated with living in rural areas (ROBBE et al., 2016), which may explain the low frequency of seropositive dogs in the present study, given that all the dogs investigated originated from the urban zone of João Pessoa.

Access to the streets among these dogs was a risk factor for infection with T. gondii in the present study. Similar results were described by Lopes et al. (2011) in Portugal, such that dogs with 
access to the streets had a higher chance of presenting anti-T. gondii antibodies. Dantas et al. (2013) stated that dogs that had access to the streets were 4.6 times more likely to be seropositive for $T$. gondii. Access to the streets provides greater possibilities for dogs to eat intermediate hosts such as birds and rodents, which are common sources of T. gondii infection (SVOBODA \& SVOBODOVÁ, 1987), and for them to consume sporulated oocysts that are present in water and in the environment.

Gennari et al. (2015) evaluated wild rodents and marsupials of the Atlantic Forest in the state of São Paulo and found that some individuals were seropositive for $T$. gondii. This suggested that these animals might be sources of infection for the fauna of the region and for domestic animals. In the present study, it was observed that dogs living in homes that were close to forested areas presented greater risk of infection with $T$. gondii. In the municipality of João Pessoa, there is an area of preserved Atlantic Forest (Figure 1) covering an area of more than 515 hectares that borders 25 districts of the city (CAVALCANTI, 2013). Moreover, there are several other areas with thick plant cover. Because of this proximity between city districts and forested areas, it is believed that this facilitates contact with a wide variety of sources of $T$. gondii infection, which increases the possibility of disease transmission.

The occurrence of toxoplasmosis and the risk factors for this disease found among the dogs of this study emphasize the importance of monitoring not only this disease in the canine population, but also various other zoonotic diseases of importance for public health. The changes that have stemmed from urbanization and deforestation of previously unexploited areas have altered the behavior and speed of propagation and appearance of these diseases. Thus, an in-depth approach addressing the ecosystem, based on multidisciplinary concepts of public health, is needed (KARESH et al., 2012; MWANGI et al., 2016).

\section{Conclusion}

The dogs attended at veterinary clinics in João Pessoa are exposed to infections caused by $T$. gondii and $N$. caninum. Dog owners should avoid having access to the street or contact with forest environments.

\section{References}

Acosta ICL, Centoducatte LD, Soares HS, Marcili A, Gondim MFN, Rossi JL Jr, et al. Occurrence of Neospora caninum and Toxoplasma gondii antibodies in dogs from rural properties surrounding a biological reserve, Espirito Santo, Brasil. Rev Bras Parasitol Vet 2016; 25(4): 536539. PMid:27925068. http://dx.doi.org/10.1590/s1984-29612016075.

Azevedo SS, Batista CS, Vasconcellos SA, Aguiar DM, Ragozo AM, Rodrigues AA, et al. Seroepidemiology of Toxoplasma gondii and Neospora caninum in dogs from the state of Paraíba, Northeast region of Brazil. Res Vet Sci 2005; 79(1): 51-56. PMid:15894024. http://dx.doi.org/10.1016/j. rvsc.2004.10.001.

Bandini LA, Neto AFA, Pena HFJ, Cavalcante GT, Schares G, Nishi SM, et al. Experimental infection of dogs (Canis familiaris) with sporulated oocysts of Neospora caninum. Vet Parasitol 2011; 176(2-3): 151-156. PMid:21094584. http://dx.doi.org/10.1016/j.vetpar.2010.10.047.
Bresciani KDS, Costa AJ, Navarro IT, Toniollo GH, Sakamoto CAM, Arantes TP, et al. Toxoplasmose canina: aspectos clínicos e patológicos. Semina: Ciênc Agrár 2008; 29(1): 189-202. http://dx.doi.org/10.5433/16790359.2008v29n1p189.

Camargo ME. Improved technique of indirect immunofluorescence for serological diagnosis of toxoplasmosis. Rev Inst Med Trop Sao Paulo 1964 6(3): 117-118. PMid:14177810.

Cavalcanti RG. Influência da mata do Buraquinho sobre a qualidade da água do rio Jaguaribe [monografia]. João Pessoa: Universidade Federal da Paraíba; 2013.

Dantas SBA, Fernandes ARF, Souza OL No, Mota RA, Alves CJ, Azevedo SS. Ocorrência e fatores de risco associados às infecções por Toxoplasma gondii e Neospora caninum em cães no município de Natal, Estado do Rio Grande do Norte, Nordeste do Brasil. Cienc Rural 2013; 43(11): 2042-2048. http://dx.doi.org/10.1590/S0103-84782013001100020.

Dantas SBA, Fernandes ARF, Souza OL No, Mota RA, Alves CJ, Azevedo SS. Fatores de risco para a ocorrência de anticorpos contra Toxoplasma gondii e Neospora caninum em cães domiciliados no Nordeste do Brasil. Semina: Ciênc Agrár 2014; 35(2): 875-882. http://dx.doi.org/10.5433/16790359.2014v35n2p875

Dohoo IR, Ducrot C, Fourichon C, Donald A, Hurnik D. An overview of techniques for dealing with large numbers of independent variables in epidemiologic studies. Prev Vet Med 1997; 29(3): 221-239. PMid:9234406. http://dx.doi.org/10.1016/S0167-5877(96)01074-4.

Dubey JP. Review of Neospora caninum and neosporosis in animals. Korean J Parasitol 2003; 41(1): 1-16. PMid:12666725. http://dx.doi. org/10.3347/kjp.2003.41.1.1.

Dubey JP. Toxoplasmosis of animals and humans. 2nd ed. New York: CRC Press Taylor \& Francis Group; 2010.

Gennari SM, Ogrzewalska MH, Soares HS, Saraiva DG, Pinter A, Nieri-Bastos FA, et al. Toxoplasma gondii antibodies in wild rodents and marsupials from the Atlantic Forest, state of São Paulo, Brazil. Rev Bras Parasitol Vet 2015; 24(3): 379-382. PMid:26444068. http://dx.doi. org/10.1590/S1984-29612015045.

Hosmer DW, Lemeshow S. Applied logistic regression. 2nd ed. New York: John Wiley \& Sons; 2000.

Instituto Brasileiro de Geografia e Estatística - IBGE. Cidades e estados do Brasil [online]. Rio de Janeiro: IBGE; 2017 [cited 2017 Dec 11]. Available from: https://www.ibge.gov.br/geociencias-novoportal/ organizacao-do-territorio/estrutura-territorial/15761-areas-dos-municipios. html?t=destaques\&c=2507507

Karesh WB, Dobson A, Lloyd-Smith JO, Lubroth J, Dixon MA, Bennett M, et al. Ecology of zoonoses: natural and unnatural histories. Lancet 2012 380(9857): 1936-1945. PMid:23200502. http://dx.doi.org/10.1016/ S0140-6736(12)61678-X.

Langoni H, Fornazari F, Silva RC, Monti ET, Villa FB. Prevalence of antibodies against Toxoplasma gondii and Neospora caninum in dogs. Braz J Microbiol 2014; 44(4): 1327-1330. PMid:24688530. http://dx.doi. org/10.1590/S1517-83822013000400043.

Lindsay DS, Dubey JP, Butler JM, Blagburn BL. Mechanical transmission of Toxoplasma gondii oocysts by dogs. Vet Parasitol 1997; 73(1-2): 27-33 PMid:9477489. http://dx.doi.org/10.1016/S0304-4017(97)00048-4.

Lopes AP, Santos H, Neto F, Rodrigues M, Kwok OCH, Dubey JP, et al. Prevalence of antibodies to Toxoplasma gondii in dogs from Northeastern Portugal. J Parasitol 2011; 97(3): 418-420. PMid:21506866. http:// dx.doi.org/10.1645/GE-2691.1. 
Mwangi W, Figueiredo P, Criscitiello MF. One health: addressing global challenges at the nexus of human, animal, and environmental. PLoS Pathog 2016; 12(9): e100731. PMid:27631500. http://dx.doi.org/10.1371/ journal.ppat.1005731.

Nava AFD. Espécies sentinelas para a Mata Atlântica: as consequências epidemiológicas da fragmentação florestal no Pontal do Paranapanema, São Paulo [tese]. São Paulo: Universidade de São Paulo; 2008.

Oshiro LM, Motta-Castro ARC, Freitas SZ, Cunha RC, Dittrich RL, Meirelles ACF, et al. Neospora caninum and Toxoplasma gondii serodiagnosis in human immunodeficiency virus carriers. Rev Soc Bras Med Trop 2015; 48(5): 568-572. PMid:26516966. http://dx.doi.org/10.1590/00378682-0151-2015.

Paradies P, Capelli G, Testini G, Cantacessi C, Trees AJ, Otranto D. Risk factors for canine neosporosis in farm and kennel dogs in southern Italy. Vet Parasitol 2007; 145(3-4): 240-244. PMid:17257762. http://dx.doi. org/10.1016/j.vetpar.2006.12.013.

Paraíba. Governo do Estado. Estudo para subsidiar a criação de unidade de conservação de proteção integral da mata do Buraquinho - Paraíba [online]. João Pessoa: Secretaria de Estado dos Recursos Hídricos, do Meio Ambiente e da Ciência e Tecnologia; 2014 [cited 2017 June 26]. Available from: http://sol.sudema.pb.gov.br/arquivos/sol/download/ propostacriacaomataburaquinho.pdf

Paré J, Hietala SK, Thurmond MC. An enzyme-linked immunosorbent assay (ELISA) for serological diagnosis of Neospora sp. infection in cattle. J Vet Diagn Invest 1995; 7(3): 352-359. PMid:7578451. http://dx.doi. org/10.1177/104063879500700310.

Pereira MDB. As chuvas na cidade de João Pessoa: uma abordagem genética [monografia]. João Pessoa: Universidade Federal da Paraíba; 2014.

Raimundo JM, Guimarães A, Moraes LMB, Santos LA, Nepomuceno LL, Barbosa SM, et al. Toxoplasma gondii and Neospora caninum in dogs from the state of Tocantins: serology and associated factors. Rev Bras Parasitol Vet 2015; 24(4): 475-481. PMid:26689184. http://dx.doi. org/10.1590/S1984-29612015068.
Reichel MP, Alejandra Ayanegui-Alcérreca M, Gondim LFP, Ellis JT. What is the global economic impact of Neospora caninum in cattle - the billion dollar question. Int J Parasitol 2013; 43(2): 133-142. PMid:23246675. http://dx.doi.org/10.1016/j.ijpara.2012.10.022

Robbe D, Passarelli A, Gloria A, Di Cesare A, Capelli G, Iorio R, et al. Neospora caninum seropositivity and reproductive risk factors in dogs. Exp Parasitol 2016; 164: 31-35. PMid:26873272. http://dx.doi.org/10.1016/j. exppara.2016.02.003.

Rodrigues JY, Almeida ABPF, Boa Sorte EC, Gasparetto ND, Cruz FACS, Sousa VRF. Seroprevalence of Toxoplasma gondii in dogs of riverside communities of Mato Grosso Pantanal, Brazil. Rev Bras Parasitol Vet 2016; 25(4): 531-535. PMid:27925062. http://dx.doi.org/10.1590/ s1984-29612016067.

Sousa ME, Porto WJN, Albuquerque PPF, Souza OL No, Pinheiro JW Jr, Mota RA. Seroprevalence of antibodies to Neospora caninum in dogs in the state of Alagoas, Brazil. Rev Bras Parasitol Vet 2012; 21 (3): 287-290. PMid:23070441. http://dx.doi.org/10.1590/S1984-29612012000300019.

Svoboda M, Svobodová V. Effects of breed, sex, age, management and nutrition on the incidence of Toxoplasma gondii antibodies in dogs and cats. Acta Vet Brno 1987; 56(3): 315-330. http://dx.doi.org/10.2754/ avb198756030315.

Thrusfield M. Epidemiologia veterinária. 2. ed. São Paulo: Roca; 2004.

Ullmann LS, Guimarães FF, Fornazari F, Tomé RO, Camossi LG, Greca $\mathrm{H}$, et al. Ações de vigilância continuada, papel do cão como animal sentinela para toxoplasmose. Rev Bras Parasitol Vet 2008; 17(Suppl 1): 345-347. PMid:20059876.

Zinsstag J, Schelling E, Waltner-Toews D, Tanner M. From "one medicine" to "one health" and systemic approaches to health and well-being. Prev Vet Med 2011; 101(3-4): 148-156. PMid:20832879. http://dx.doi. org/10.1016/j.prevetmed.2010.07.003. 